\title{
MULTILITERACY LITERATURE MODELS: SOLUTIONS FOR READING LEARNING MODELS IN THE COVID-19 PANDEMIC ERA
}

\author{
Submitted: \\ 3 Oktober 2021 \\ Accepted: \\ 18 November 2021 \\ Published: \\ 31 Januari 2022
}

\author{
Rianita Kartika Eka Putri ${ }^{1}$, Yunus Abidin*2, S. Nailul Muna \\ Aljamaliah $^{3}$ \\ rianita.kartika0495@gmail.com¹,yunusabidin@upi.edu², \\ syifanailul@upi.edu ${ }^{3}$ \\ Universitas Pendidikan Indonesia ${ }^{1,2,3}$ \\ *Corresponding Author
}

\begin{abstract}
This study aims to examine the effectiveness of the literature multiliteracy model on the students' ability to understand illustrated fairy tales in elementary school students. The quasi-experimental method was used in this study. The sample of this research is elementary school students in Bandung city who were selected by purposive sampling technique. The instrument used is a product assessment sheet that retells fairy tales in the form of a zig-zag book. The results showed that the multiliteracy literature model was effective in improving students' ability to understand illustrated fairy tales in elementary school students. Based on this, the literature multiliteracy model can be used as an alternative model in learning in elementary schools.
\end{abstract}

Keywords: literature multiliteracy model, reading comprehension, pandemic era

\section{INTRODUCTION}

The ability to read and understand is an important ability possessed by all humans in the 21st-century era. A deep understanding of a concept is a basic thing in developing other abilities, both thinking skills and the ability to communicate and collaborate. The importance of reading skills in the 21 st century is stated explicitly by ConcannonGibney \& McCarthy (2012) that all students in this century need good reading skills to solve increasingly complex life problems.

However, for Indonesian students, the reading comprehension ability is still a problem in itself along with the fact that their reading ability is still low. This is reinforced by the results of PISA 2018 (OECD, 2019) which stated that the reading skills of Indonesian students are still low, which is only up to level two proficiency. This ability proves that Indonesian students are only able to identify the main idea of a medium-length text, only able to find information that is explicitly contained in the text, and only able to reflect on the purpose of a text whose information is stated in that text. 
The weak reading comprehension ability of students is also indicated by the tendency of students to answer they don't know when students do a question based on a story. In addition, students also have not been able to retell the stories contents they have read and there are even some students who are lazy to read stories (Kharizmi, 2015; Dewi, 2015; Hidayah, 2011). Other studies even prove that the low reading comprehension ability of students is also associated with low scientific literacy skills and mathematical literacy (Diana, Rachmatulloh, \& Rahmawati, 2015; Nofiana \& Julianto, 2017; Laily, 2014).

This low reading comprehension ability is certainly caused by several factors, including students who are not familiarized and introduced to reading materials, reading learning activities are not optimal, and the use of models or methods used by teachers is not appropriate and not optimal. Teachers tend not to use any models or methods in reading learning, causing students to be less interested and lazy to read because reading activities are carried out monotonously and do not attract students' interest in reading.

Based on the problems above, efforts that can be done are to use an innovative model that is suitable for the pandemic conditions in particular. One of the models that researchers use as a solution to the problems above is the multiliteracy literature model. This model is innovative because in addition to improving student's reading comprehension. Several studies have also revealed that this model can make learning meaningful and fun; increasing student activity in reading comprehension and being able to increase student creativity and make students enthusiastic about reading (Rahman \& Damaianti, 2019; Jaenudin, Puspitasari, \& Cahyaningsih, 2019; Dafit, 2017; Astuti \& Iku, 2020).

This study aims to determine the effectiveness of the multiliteracy literature model on increasing students' understanding of illustrated fairy tales. The results of this study can be important information about whether or not the multiliteracy literature model can be used during a pandemic to improve students' ability to understand illustrated fairy tales so that teachers can use the right model for reading learning during a pandemic.

\section{METHOD}

This study used quantitative research and the research method used is experimental research, the type of pretest-posttest design is not equivalent. This design 
involves at least two sample groups whose subjects are not randomly selected (Creswell, 2015). In practice, each group received 5 times of learning treatment with a balanced time and composition of tasks. Learning is carried out face-to-face using various communication channels, including zoom meetings and Whatapps in line with the ongoing Covid-19 pandemic.

The population that will be used in this research is all 3rd-grade students in the 2021/2022 academic year at SDN in Bandung city. Samples used by the researcher are class $3 \mathrm{~B}$ and class $3 \mathrm{~A}$ as the experimental and control classes. The reading product assessment sheet was used as an instrument in this study. The learning product outcome was a zig-zag book that contained a retelling of the text read.

This study used inferential statistical data analysis techniques, that is concluding results of data. This analysis is quantitative, that is acquisition of student score data from two sample classes. The test was carried out using a mutually exclusive t-test to determine the effectiveness of the applied model in learning in the pandemic era.

\section{RESULTS}

This research was carried out first by doing a pretest for two sample classes. The pretest was conducted to provide confidence that the understanding of sample students was relatively the same. The data were obtained then analyzed by researchers using descriptive statistical tests with the following results.

Table 1

\section{Descriptive Statistics of Pretest Score}

\begin{tabular}{|c|c|c|c|c|c|c|}
\hline \multicolumn{7}{|c|}{ Descriptive statistics } \\
\hline & N & Minimum & Maximum & Average & $\begin{array}{c}\text { Std. } \\
\text { Deviation }\end{array}$ & variance \\
\hline Control Pretest & 20 & 15 & 52 & 32.85 & 7.386 & 54,555 \\
\hline Experiment Pretest & 20 & 16 & 56 & 36.25 & 8,577 & 73.566 \\
\hline
\end{tabular}

(Source: Research Result Data Analysis)

Based on the data above, it can be seen that the average pretest value in the experimental class is greater than the pretest value in the control class. There is a difference between the pretest scores in the two classes, which is 3.41 . The average value of the two sample groups can be seen in the boxplot in Figure 1 

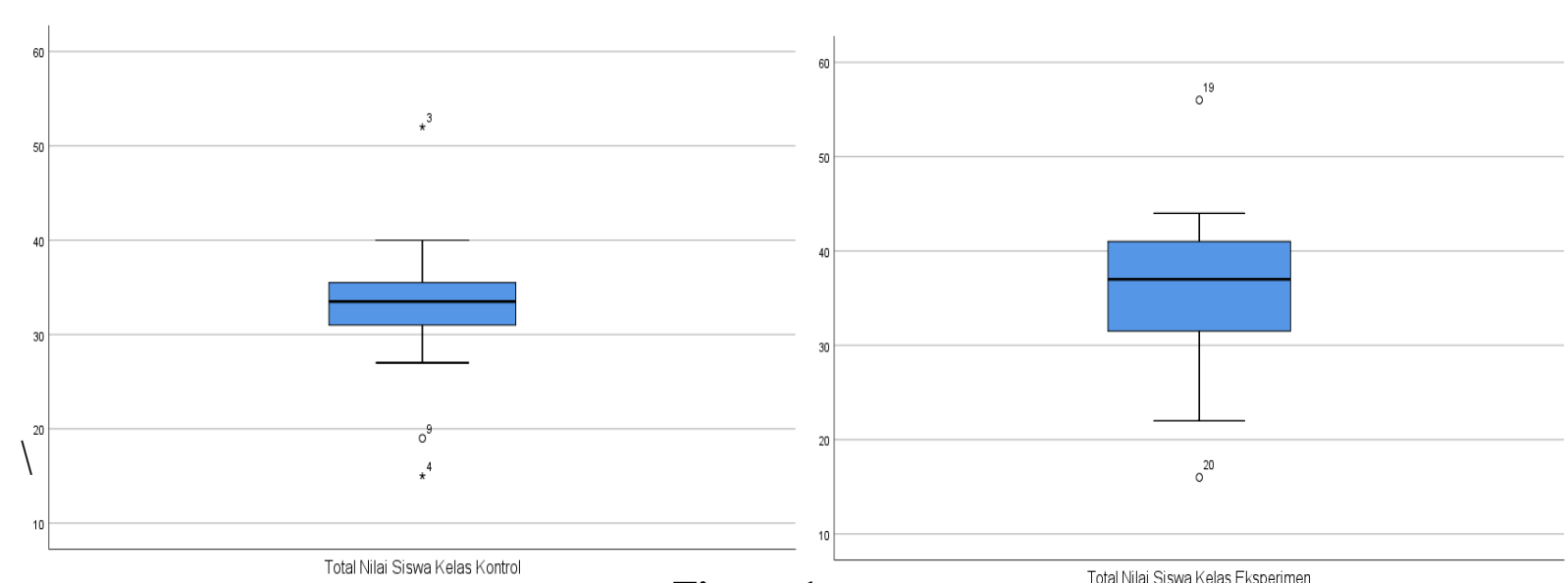

Figure 1

Boxplot Pretest Score

To determine the effectiveness of the two models used, an average difference test was conducted. Based on the prerequisite test of analysis of the data normality test, it is known that two samples of data are not normally distributed. Therefore, the difference average data was carried out using the Mann-Whitney test with the following results.

Table 2

Table of Differences average in Pretest Score

\begin{tabular}{|c|r|}
\hline & Total Pretest Score \\
\hline Mann-Whitney U & 130,000 \\
\hline Wilcoxon W & 340,000 \\
\hline Z & $-1,900$ \\
\hline asymp. Sig. (2-tailed) & .057 \\
\hline
\end{tabular}

(Source: Research Result Data Analysis)

Based on a test using the Mann-Whitney test, the $U$ value is 130,000 with a significance value of 0.057 which is greater than the normal level set (0.05). These results indicate that there is no statistically significant difference between the ability of control and experimental students in reading comprehension of illustrated fairy tales in early classes.

After it was known that the student's abilities in the two classes were relatively the same, the study continued by carrying out 5 times learning treatment in experimental class applying the multiliteracy literature model and using the Know Want to Learned (KWL) model in the control class. After the treatment was carried out in a fair and balanced manner, then a post-test was conducted to determine the students' reading 
comprehension skills in illustrated fairy tales in both post-treatment classes. Two data were processed descriptively with the following results.

Table 3

Descriptive Statistics Pretest Score Posttest Score

\begin{tabular}{|c|c|c|c|c|c|c|}
\hline \multicolumn{7}{|c|}{ Descriptive Statistics } \\
\hline & $\mathrm{N}$ & Min & Max & Average & Std. Deviation & variance \\
\hline Control Class Posttest & 20 & 24 & 61 & 43.50 & 11,642 & 135.526 \\
\hline Experiment Class Posttest & 20 & 41 & 72 & 61.60 & 8,792 & 77.305 \\
\hline
\end{tabular}

(Source: Research Result Data Analysis)

Based on the data above, it can be seen that the average posttest score in the control class is 43.50 . The average score of posttest score in the experimental class was 61.60. When compared with the pretest data, students in both classes experienced an increase in reading ability. In the experimental class, students experienced 10.65. The average score of the two sample groups can be seen in the boxplot below.

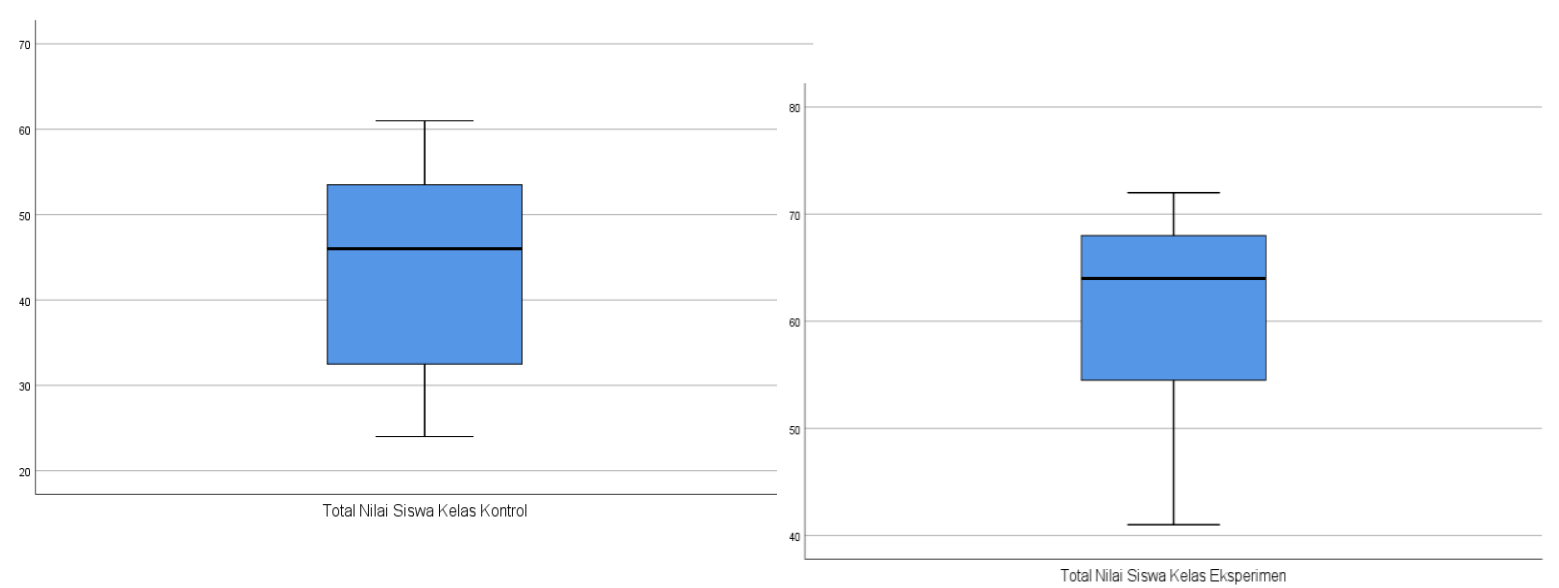

Figure 2

Boxplot of Posttest Values for Experiment Class and Control Class

To answer research questions, an average difference test was conducted. Based on the results of the pre-requisite analysis of the two pairs of normal and homogeneous data, an independent sample t-test was conducted. The test results are stated as follows. 
Table 4

Test Independent t-Test

\begin{tabular}{|c|c|c|c|c|c|c|c|c|c|c|}
\hline & \multicolumn{2}{|c|}{$\begin{array}{l}\text { Levene's Test } \\
\text { for Equality of } \\
\text { Variances }\end{array}$} & \multicolumn{7}{|c|}{ t-test for Equality of Means } \\
\hline & & \multirow[b]{2}{*}{$\mathrm{F}$} & \multirow[b]{2}{*}{ Sig. } & \multirow[b]{2}{*}{$\mathrm{t}$} & \multirow[b]{2}{*}{$\mathrm{df}$} & \multirow{2}{*}{$\begin{array}{l}\text { Sig. } \\
(2- \\
\text { tailed })\end{array}$} & \multirow{2}{*}{$\begin{array}{c}\text { Mean } \\
\text { Difference }\end{array}$} & \multirow{2}{*}{$\begin{array}{l}\text { Std. Error } \\
\text { Difference }\end{array}$} & \multicolumn{2}{|c|}{$\begin{array}{c}95 \% \\
\text { Confidence } \\
\text { Interval of the } \\
\text { Difference }\end{array}$} \\
\hline & & & & & & & & & Lower & Upper \\
\hline \multirow[t]{2}{*}{$\begin{array}{l}\text { Posttest } \\
\text { Results }\end{array}$} & $\begin{array}{c}\text { Equal } \\
\text { variances } \\
\text { assumed }\end{array}$ & 2.286 & .139 & 5.548 & 38 & .000 & 18,100 & 3.262 & 11,496 & 24,704 \\
\hline & $\begin{array}{c}\text { Equal } \\
\text { variances } \\
\text { not assumed }\end{array}$ & & & 5.548 & 35,354 & .000 & 18,100 & 3.262 & 11.480 & 24,720 \\
\hline
\end{tabular}

(Source: Research Result Data Analysis)

Based on this calculation, the t score is 5, 548 with a sig. score (2-tailed) of 0.000 which is smaller than 0.05 . On this basis, it can be interpreted that the literature multiliteracy model applied in the experimental class is more effectively used to improve understanding than the KWL model used in the control class.

\section{DISCUSSION}

Based on the analysis results of pretest data and posttest data that has been carried out on the two sample groups, it can be seen that the literature multiliteracy model in the experimental class and the KWL model in the control class are equally influential in each class. However, if you look at the analysis results further, it shows that the results of the posttest average score of the experimental class are higher, it is 61.60 while the average posttest score of the control class is lower, that is 43.50 so this indicates that the multiliteracy literature model is more suitable and effective to be applied in learning reading comprehension in illustrated fairy tales.

The different effect of the two models used shows that the learning step with the multiliteracy literature model is more effective in improving students' ability to understand a text. On this basis, it is necessary to discuss in depth the reasons why the multiliteracy literature model is considered more capable of improving students' abilities.

In experimental class, learning begins with the stages of exploring students' schemata. The process of digging schemata is done to revive students' prior knowledge 
before reading fairy tales. At this stage, teachers and students conduct questions and answers to provoke students to convey their ideas. The process of digging schemata is important to do because, with the initial abilities students have, it will be easy to understand a text they are reading. Al-Issa (2006) stated that one's understanding is determined by how much initial knowledge one has when reading. The more knowledge students have, the more understanding students will experience. Abidin (2015) further stated that reading activities to gain understanding are strongly influenced by the initial knowledge or schemata that students have. Students who have schemata will also find it easier to draw the meaning or message contained in a text.

This second stage is making predictions. Before making predictions, teachers read some of the fairy tales to the part where problems begin to arise. Students are asked to make predictions or guess what the story will be like. At this stage, students make predictions with the knowledge they already have. Based on the research findings, at this stage some students have difficulty in making predictions, some students can make predictions, so they need a stimulus from the teacher so that students can make predictions. Whereas in Damaianti's view (2021) the ability to make predictions in reading activities will provide a better understanding of the reading content.

Entering the reading stage to find out if the students' answers are correct or not, teachers give a text to students to read as a whole. When this reading process they have a few obstacles, teachers are difficult to condition students in reading. However, this can be resolved properly because teachers provide two options for students to be able to read the reading text through a file sent by them on Whatsapp and the second option for the teacher to display the text through a powerpoint which is shared on a zoomed screen. Teachers give 5-7 minutes for students to read the fairy tale text. Students are asked to concentrate when reading and in silence. However, based on the findings, some students did not turn off their microphones so they heard disturbing sounds. This reading activity through zoom has a deficiency, but the teacher can overcome this, and learning is carried out well.

The next stage is students analyzing the intrinsic elements of fairy tales. In this activity, students write it down in the LKPD which is distributed by the teacher. This is to make it easier for students to write down important information such as writing background elements. In the study findings, when students analyzed a text, students did 
not have difficulties, even though students had time to ask their teacher about the setting of the atmosphere, but learning was still going well. In addition, students are asked to write down the characters and analyze their characteristics of the characters. This written information can help students when students rewrite the story using their language. This is in line with the statement of USAID Prioritas (2014) which stated that the use of LKPD to write down children's reading results will be able to become a basic guide for children to rewrite the contents of reading in their language.

The next stage is that students are asked to transform a text they have read. In this case, students rewrite the story using their language. Students write their understanding in writing into a post-reading work. When students can write stories using their own language, it can be seen that the level of students' understanding of the reading contents is good. Dalman (2013) stated that when a reader can retell the reading contents either implicitly or explicitly, a reader is said to have understood a text he has read because he can rewrite the story both orally and written. Students are also asked to analyze the messages/moral value contained in the fairy tales that have been read. The message/moral value of this fairy tale is related to the daily life of students.

The last stage is the students are asked to pour all the information that has been obtained previously into work in the form of a zig-zag book. In a zigzag book, students retell the contents of a fairy tale they have read using their own language. Students are also asked to describe the characters in the story. In describing characters, students can see the pictures in fairy tales, because this fairy tale is an illustrated fairy tale. This activity stimulates students to distribute their talents in drawing or it can be said that students with good visual abilities can express their talents when they are drawing. In this regard, Susilo \& Garnisya (2018) stated that reading is a complex activity that involves mental activity so that by making this product students not only get important information from texts, students can also create a work or creative product. This creative product is the result of reading students' understanding of illustrated fairy tales. This is reinforced by Abidin, Mulyati \& Yunansyah (2017) who said that reading is a form of experience; The reader has the opportunity to know the author's thoughts through the text he wrote so that it will produce a complete understanding based on the meaning contained in the text he reads. This understanding is creative so that when 
students produce a product, the product is an extension of the understanding that they get.

The final scores of students both increased, but the increase was higher in the experimental class. In each indicator, it seems differences in students' reading comprehension abilities, it can be seen that the average score of the two classes is quite different. There is a one almost equivalent indicator, namely the indicator of writing titles. Thus, it is clear that the literature multiliteracy model is more suitable and effective to be applied in the reading learning process. In line with the results of the comparison above, the research of Nuraeni \& Rohendi (2016) has also proven that the literature multiliteracy model has proven to be effective in increasing students' understanding of reading legends. Based on his research results, it is known that the literature multiliteracy model can make learning more interesting and creative and make students more fond of reading, especially reading legends. Eriyan (2018) also proved that the literature multiliteracy model is more suitable to be used to improve students' understanding of fictional texts. This model also familiarizes students with writing and familiarizes students with making works, that is retelling the contents of readings that have been read using their own language.

Despite the successes achieved, this research certainly has its drawbacks. These shortcomings include, learning through zoom has a high risk, such as signals, the availability of gadgets owned by students so that it affects student participation in learning; limited learning time; and teachers find it difficult to condition the class (Sarifudin, et al. 2021). However, in the research that has been done by researchers, learning can be said to be quite effective. This is because students can follow the lesson well. It's just that not all students can take part in the learning so that learning is only attended by 20 students out of 28 people.

Another weakness is at the stage of making a work of student understanding in the form of a zig-zag book. The stage of making work takes quite a long time. Although students are very enthusiastic about making zigzag book works, students are still focused on making pictures and decorating the zigzag book. To overcome this, students are advised to write the story first and then to draw the characters and decorate the zigzag book. Due to time constraints, some students continue to make works outside of Zoom. On this basis, further consideration is needed in choosing post-reading works 
that save more time, such as mini books, story calendars, and other creative media that remain interesting and challenging for students.

\section{CONCLUSION}

This study concludes that the literature multiliteracy model is effectively applied in the pandemic era through online learning to improve students' understanding of reading illustrated fairy tales. This effect is seen after 5 times of learning treatment as evidenced by the different abilities of students in the experimental class and the difference in posttest scores between the two sample classes. Thus, the literature multiliteracy model was effectively applied in the experimental class and more effective when compared to the comparison model in the control class.

Based on these conclusions, this study recommends teachers be able to use this model so that reading learning, especially reading comprehension, becomes more interesting and meaningful. This model can be used as an innovation for teachers because through this model students are not only able to answer questions but are also able to pour their understanding into creative works. For the weakness of the stage of making works, it is recommended that further research be able to choose the type of reading product that is more creative and saves time such as mini books and or the use of digital media.

\section{REFERENCES}

Abidin, Y. (2015) Pembelajaran Multiliterasi: Sebuah Jawaban Atas Tantangan Pendidikan Abad Ke-21 dalam Konteks Keindonesiaan. Bandung: Refika Aditama.

Abidin, Y., Mulyati, T., \& Yunansyah, H. (2017) Developing Literacy Learning Model Based on Multiliteracy, Integrated, and Differentiated Concept at Primary School. Cakrawala Pendidikan. XXXVI (2). 156-166.

Al-Issa, A. (2006). Schema Theory and L2 Reading Comprehention: Implications for Teaching. Journal of College Teaching \& Learning. 3 (7). 41-48.

Astuti, N. \& Iku, P.F. (2020) Pembelajaran Multiliterasi sebagai Wahana Peningkatan Keterampilan Belajar Siswa Di Masa Pandemi Covid 19. Aliterasi: Jurnal Pendidikan, Bahasa dan Sastra. 1(01).12-18.

Concannon-Gibney, T. and McCarthy, M.J. (2012). The Explicit Teaching of Reading Comprehension in Science Class: a Pilot Professional Development Program”. Improving Schools. 15 (1). 73-88. 
Creswell, J.W. (2015). Educational Research: Planning, Conductiong, and Evaluating Quantitative and Qualitative Research. New York: Pearson Merril Prentice Hall.

Dafit, F. (2017) Implementasi Model Multiliterasi pada Proses Pembelajaran Membaca Pemahaman Siswa Kelas IV Sekolah Dasar. Jurnal Sekolah (JS). 1 (2). 53 - 59.

Dalman (2013). Keterampilan Membaca. Jakarta: PT Rajagrafindo Persada

Damaianti, V.S. (2021) Literasi Membaca: Hasrat Memahami Makna Kehidupan. Bandung: Refika Aditama.

Dewi, S.U.S. (2015) Pengaruh Metode Multisensori dalam Meningkatkan Kemampuan Membaca Permulaan pada Anak Kelas Awal Sekolah Dasar. MODELING: Jurnal Program Studi PGMI. 3 (1). 1-13.

Diana, S., Rachmatulloh, A., \& Rahmawati, E.S. (2015) Profil Kemampuan Literasi Sains Siswa SMA Berdasarkan Instrumen Scientific Literacy Assesments (SLA). Prosiding Seminar Nasional XII Pendidikan Biologi FKIP UNS. Solo: FKIP UNS.

Eriyan, W. (2018). Pengaruh Model Multiliterasi Literatur dengan Model Directed Reading Thinking Activity (DRTA) terhadap Kemampuan Membaca Pemahaman Fiksi Siswa. Skripsi Tidak Diterbitkan. Bandung: Universitas Pendidikan Indonesia.

Hidayah, R. (2011). Profil Kemampuan Membaca Siswa Kelas 5 Sekolah Dasar (SD) dan Madrasah Ibtidaiyah (MI) Ditinjau dari Jenis Sekolah dan Jenis Kelamin. Madrasah. 4 (1). 60-80.

Jaenudin, J., Puspitasari, W.D., \& Cahyaningsih, U. (2019) Penerapan Model Multiliterasi untuk Meningkatkan Kemampuan Membaca Pemahaman. Prosiding Seminar Nasional Pendidikan "Literasi Pendidikan Karakter Berwawasan Kearifan Lokal pada Era Revolusi Industri 4.0” Universitas Majalengka. 8 Agustus 2019. Majalengka: FKIP Universitas Majalengka.

Kharizmi, M. (2015) Kesulitan Siswa Sekolah Dasar dalam Meningkatkan Kemampuan Literasi. JUPENDAS. 2 (2). 11-21.

Laily, I.F. (2014) Hubungan Kemampuan Membaca Pemahaman dengan Kemampuan Memahami Soal Cerita Matematika Sekolah Dasar. EduMa. 3 (1). 52-62.

Nofiana, M. \& Julianto, T. (2017) Profil Kemampuan Literasi Sains Siswa SMP di Kota Purwokerto Ditinjau dari Aspek Konten, Proses, dan Konteks Sains. Junal Sains Sosial dan Humaniora (JSSH). I (2). 77- 84.

Nuraeni, S. \& Rohendi, E. (2016). Penggunaan Model Multiliterasi Literatur untuk Meningkatkan Kemampuan Membaca Pemahaman Cerita Legenda. Jurnal PGSD Kampus Cibiru. 2016 (2). 110 - 125.

OECD. (2019). PISA 2018 Results (Volume I): What Students Know and Can Do. Canada: OECD. https://doi.org/10.1787/5f07c754-en

Rahman, F.U. \& Damaianti, V.S. (2019) Model Multiliterasi Kritis dalam Pembelajaran Siswa Sekolah Dasar. JPD: Jurnal Pendidikan Dasar. 10 (1). 27 - 34.

Sarifudin, A., dkk. (2021) Pembelajaran Digital Inovatif Berbasis Multiplatform. Bandung: Yayasan Lembaga Pendidikan dan Pelatihan Multiliterasi. 
Susilo, S. V. \& Garnisya, G.R. (2018). Penerapan Model Multiliterasi Untuk Meningkatkan Kemampuan Membaca Pemahaman Siswa Sekolah Dasar. Jurnal Cakrawala Pendas. 4 (2). 66-71.

USAID Prioritas (2014) Praktik yang Baik dalam Pembelajaran di Sekolah Dasar dan Madrasah Ibtidaiyah (SD/MI). Jakarta: USAID 